\title{
Sirolimus-Induced Hepatitis in Two Patients with Hyperinsulinemic Hypoglycemia
}

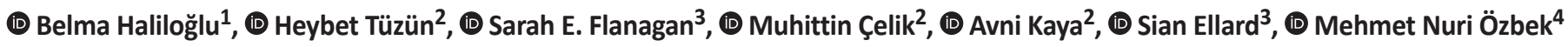 \\ 1 Yeditepe University Faculty of Medicine, Department of Pediatric Endocrinology, İstanbul, Turkey \\ 2 Diyarbakır Child Health Hospital, Clinic of Neonatology, Diyarbakır, Turkey \\ 3 University of Exeter Medical School, Institute of Biomedical and Clinical Science, Exeter, United Kingdom \\ 4 University of Health Sciences, Diyarbakır Gazi Yaşargil Training and Research Hospital, Clinic of Pediatric Endocrinology, Diyarbakır, Turkey
}

\section{What is already known on this topic?}

Sirolimus is an alternative for the treatment of congenital hyperinsulinism unresponsive to diazoxide and octreotide.

\section{What this study adds?}

This is the first report of sirolimus-induced hepatitis in pediatric patients with hyperinsulinemic hypoglycemia.

\begin{abstract}
Sirolimus has been reported to be effective in the treatment of the diffuse form of congenital hyperinsulinism (CHI), unresponsive to diazoxide and octreotide, without causing severe side effects. Two newborns with $\mathrm{CHI}$ due to homozygous $A B C C 8$ gene mutations were started on sirolimus aged 21 and 17 days, due to lack of response to medical treatment. A good response to sirolimus was observed. At follow-up after ten and two months of treatment, liver enzymes were found to be increased [serum sirolimus level 1.4 ng/mL (normal range: 5-15), aspartate aminotransferase (AST): 298U/L, alanine aminotransferase (ALT): 302U/L and serum sirolimus level: 9.9 ng/mL, AST: $261 \mathrm{U} / \mathrm{L}$, ALT: $275 \mathrm{U} / \mathrm{L}$, respectively]. In Case 1, discontinuation of the drug resulted in normalization of liver enzymes within three days. Two days after normalization, sirolimus was restarted at a lower dose, which resulted in a repeated increase in transferases. In Case 2, a reduction of sirolimus dose caused normalization of liver enzymes within ten days. When the dose was increased, enzymes increased within three days. Sirolimus was discontinued in both cases.

The rapid normalization of liver enzyme levels after sirolimus withdrawal or dose reduction; elevation of transaminases after restart or dose increase and rapid normalization after sirolimus withdrawal were findings strongly suggestive of sirolimus-induced hepatitis.

To the best of our knowledge, this is the first report of sirolimus-induced hepatitis in CHI. Sirolimus is a promising drug for CHI patients who are unresponsive to medical treatment, but physicians should be vigilant for adverse effects on liver function.
\end{abstract}

Keywords: Hyperinsulinemic hypoglycemia, sirolimus, hepatitis, liver enzymes

\section{Introduction}

Congenital hyperinsulinism $(\mathrm{CHI})$ is characterized by inappropriate insulin secretion despite hypoglycemia. It is a heterogeneous disorder with the clinical manifestations ranging from severe hypoglycemia in the newborn period to mild hypoglycemia in childhood $(1,2)$. The incidence is approximately 1:30.000 live births but is increased in populations with a high prevalence of consanguinity
(3). Most cases of $\mathrm{CHI}$ are caused by autosomal recessive mutations in the $A B C C 8$ and $K C N J 11$ genes (1).

Historically the treatment of severe, diffuse $\mathrm{CHI}$, unresponsive to diazoxide and octreotide was subtotal pancreatectomy. This surgery has been associated with a high incidence of insulin-dependent diabetes, persistent hypoglycemia and exocrine pancreatic insufficiency (4). As a novel agent, the mammalian target of rapamycin 
(mTOR) inhibitor, sirolimus, has been recommended for the treatment of the diffuse form of $\mathrm{CHI}$, unresponsive to diazoxide and octreotide. It has been reported to be a safe agent in pediatric cases $(5,6,7)$. Herein, we report two cases of diazoxide and octreotide unresponsive $\mathrm{CHI}$, due to homozygous $A B C C 8$ gene mutations in which sirolimus had to be discontinued because of drug related hepatotoxicity.

\section{Case Reports}

\section{Case 1}

A female infant presented with severe hypoglycemia on the first day of life. CHI was diagnosed based on laboratory findings. She was normoglycemic with intravenous (iv) glucose, diazoxide, iv glucagon and octreotide on day 16 but the reduction in glucose requirement was not successful during the next five days (Table 1). She also had congenital hypothyroidism with normal thyroid ultasonography (TSH: $>100 \mathrm{uIU} / \mathrm{mL}$, sT4:0.7 ng/dL) and was euthyroid with L-thyroxine (12 $\mathrm{mcg} / \mathrm{kg} /$ day $)$.

18F-DOPA positron emission tomography/computed tomography (PET/CT) scanning could not be performed but sequence analysis identified a novel homozygous p.H59P (c.176A $>$ C) missense mutation in the proband's $A B C C 8$ gene. In silico analysis predicted the variant was likely to be pathogenic and that the affected residue was highly conserved across species (Alamut, Rouen, France). The identification of a recessively inherited ABCC 8 mutation in the patient was consistent with diffuse pancreatic disease.

\begin{tabular}{|c|c|c|}
\hline & Case 1 & Case 2 \\
\hline Sex & Female & Female \\
\hline Birth weight & $3300 \mathrm{~g}$ & $3100 \mathrm{~g}$ \\
\hline Gestation week & 39 wks & 36 wks \\
\hline Blood glucose level (mg/dL) & 26 & 20 \\
\hline Blood insulin level (mIU/mL) & 55 & 43 \\
\hline \multirow[t]{2}{*}{ Genetic result } & $A B C C 8$ gene & $A B C C 8$ gene \\
\hline & $\begin{array}{l}\text { p.H59P } \\
\text { homozygote }\end{array}$ & $\begin{array}{l}\text { p.A1185E } \\
\text { homozygote }\end{array}$ \\
\hline \multicolumn{3}{|l|}{ Treatment before sirolimus } \\
\hline GPR & $18 \mathrm{mg} / \mathrm{kg} / \mathrm{min}$ & $11 \mathrm{mg} / \mathrm{kg} / \mathrm{min}$ \\
\hline Diazoxide & $15 \mathrm{mg} / \mathrm{kg} / \mathrm{d}$ & $20 \mathrm{mg} / \mathrm{kg} / \mathrm{d}$ \\
\hline Octreotide & $40 \mathrm{mcg} / \mathrm{kg} / \mathrm{d}$ & $40 \mathrm{mcg} / \mathrm{kg} / \mathrm{d}$ \\
\hline Glucagon & $0.01 \mathrm{mg} / \mathrm{kg} / \mathrm{h}$ & \\
\hline Age at sirolimus treatment & $\begin{array}{l}\text { Postnatal } 21^{\text {st }} \\
\text { day }\end{array}$ & $\begin{array}{l}\text { Postnatal } 17^{\text {th }} \\
\text { day }\end{array}$ \\
\hline
\end{tabular}

After consent from the parents, sirolimus was started at a dose of $0.5 \mathrm{mg} / \mathrm{m}^{2} /$ day on day 21 . The serum level of sirolimus and laboratory tests (full blood count, kidney and liver function tests, lipid profile, electrolytes) were checked every five days, to maintain the serum sirolimus concentration between 5-15 ng/dL. The patient was discharged on day 72 with oral feeding, subcutaneous octreotide $(40 \mathrm{mcg} / \mathrm{kg} / \mathrm{d})$ and oral sirolimus ( $3 \mathrm{mg} / \mathrm{m}^{2} /$ day). The sirolimus level and biochemical markers were checked at monthly intervals.

Since she was normoglycemic, the octreotide dose was decreased during follow-up. At the age of 10 months the patient presented with diarrhea. At this time, she was being treated with octreotide $(6 \mathrm{mcg} / \mathrm{kg} / \mathrm{d})$ and sirolimus $(3.1$ $\mathrm{mg} / \mathrm{m}^{2} /$ day) and was normoglycemic. Her laboratory tests revealed elevated liver enzymes (Table 2). The coagulation tests, bilirubin levels, alkaline phosphatase (ALP), gammaglutamyl transpeptidase (GGT) and abdominal ultrasound results were all normal. Although the sirolimus level was below the therapeutic range $(1.4 \mathrm{ng} / \mathrm{mL})$, it was discontinued due to its known hepatotoxic effect. The liver enzyme

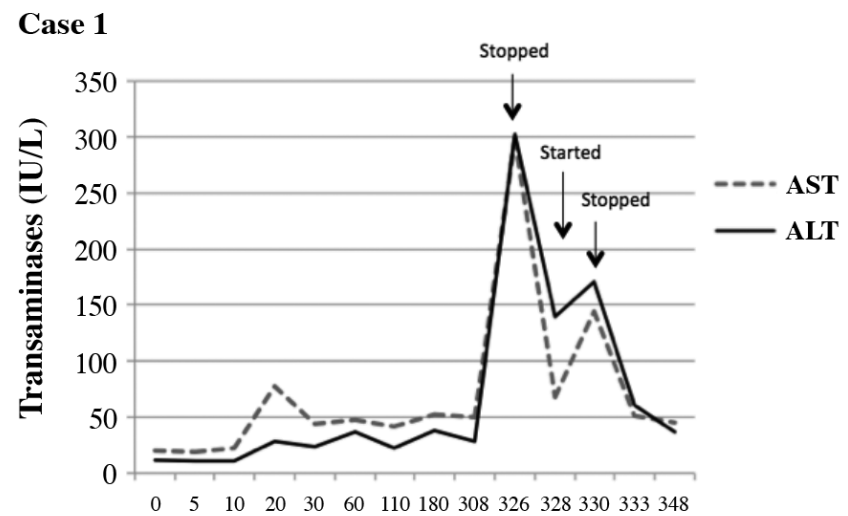

Days of Sirolimus

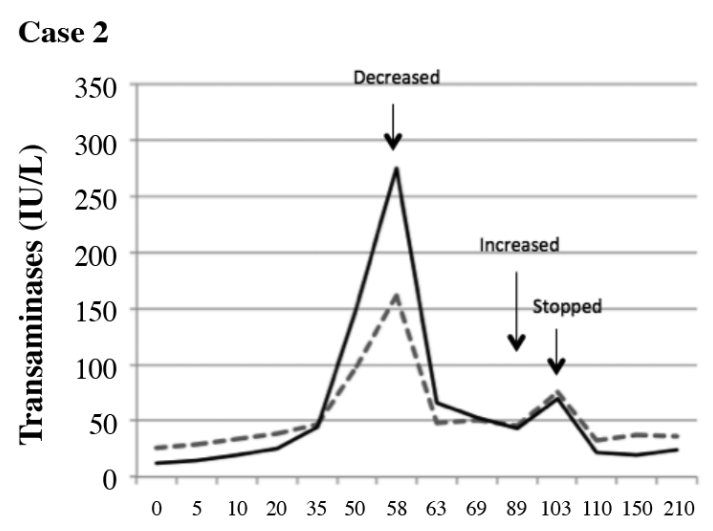

Days of Sirolimus

Figure 1. Liver enzyme levels (AST: aspartate aminotransferase, ALT: alanine aminotransferase) of Case 1 and Case 2 during sirolimus treatment and immediately after cessation 
levels during dose adjustments are shown in the Figure 1. After sirolimus was discontinued, the octreotide dose was increased to $45 \mathrm{mcg} / \mathrm{kg} / \mathrm{d}$ to achieve normoglycemia and four months later the patient was switched to octreotidelong-acting release (LAR). She is currently 18 months of age with normal neuromotor development and normoglycemia, treated solely with octreotide-LAR (15 mg/monthly, $41 \mathrm{mcg} /$ $\mathrm{kg} / \mathrm{d}$ ) and oral feedings with three hourly intervals. Her most recent $\mathrm{HbA} 1 \mathrm{c}$ level was $4.9 \%$ (30 $\mathrm{mmol} / \mathrm{mol})$ and also, she is euthyroid on L-thyroxine treatment.

\section{Case 2}

This female infant was referred to our clinic on day 14 of life with $\mathrm{CHI}$ resistant to medical therapy (Table 1) and the reduction in glucose requirement was not successful. She had also congenital hypothyroidism with normal thyroid ultrasound (TSH: > $100 \mathrm{uIU} / \mathrm{mL}$, sT4:0.9 ng/dL) and was euthyroid with L-thyroxine $(8 \mathrm{mcg} / \mathrm{kg} / \mathrm{d})$.

Sequence analysis identified a previously reported homozygous missense mutation, p.A1185E (c.3554C > A), in ABCC8 (8). The presence of a homozygous mutation in the patient was in keeping with diffuse pancreatic disease. After consent from the parents was obtained, sirolimus ( 0.5 $\mathrm{mg} / \mathrm{m}^{2} /$ day) was added, due to no reduction in the glucose requirement by day 17 . Serum levels of sirolimus were checked every five days to maintain a therapeutic serum level as before. Neither clinical nor laboratory side effects were observed. She was discharged at age 40 days with sirolimus $0.4 \mathrm{mg} / \mathrm{m}^{2} /$ day and octreotide $23 \mathrm{mcg} / \mathrm{kg} / \mathrm{d}$.

One month later, routine blood tests for side effects revealed elevated liver enzymes (Table 2) without any clinical symptoms. Sirolimus level at this time was $9.9 \mathrm{ng} / \mathrm{mL}$ in the middle of the therapeutic range. All other laboratory tests (blood count, kidney function tests, ALP, GGT, bilirubin levels) and abdominal ultrasound revealed normal results. The liver enzyme levels during dose adjustments are shown in Figure 1. As sirolimus was discontinued, the dose of octreotide was increased from 10 to $45 \mathrm{mcg} /$ $\mathrm{kg} / \mathrm{d}$. Although, the glucose levels were generally close to the lower limit of normal, with frequent oral feedings and applying a maximum dose of octreotide, we were able to protect the patient from severe hypoglycemia (a glucose level $<50 \mathrm{mg} / \mathrm{dL}$ ). Subcutaneous octreotide was switched to octreotide-LAR five months later. The patient is currently 13 months of age and normoglycemic with octreotide-LAR (15 mg/monthly, $45 \mathrm{mcg} / \mathrm{kg} / \mathrm{d}$ ) and oral feedings at 4 hours intervals. Last $\mathrm{HbA} 1 \mathrm{c}$ is $4.2 \%(22 \mathrm{mmol} / \mathrm{mol})$ and also, she is euthyroid on L-thyroxine treatment.

\section{Discussion}

The aim of treatment in $\mathrm{CHI}$ is to achieve normoglycemia and to prevent neurological damage. However, the clinical management of severe, diffuse $\mathrm{CHI}$, unresponsive to medical treatment is still a vexing clinical problem (4). In a recent study, mTOR inhibitor, sirolimus, has been reported to be a novel agent for the treatment of diazoxide unresponsive CHI. Therapy with sirolimus achieved normoglycemia with no major adverse effect in four cases (5). We now report two further cases with severe $\mathrm{CHI}$ due to a homozygous $\mathrm{ABCC} 8$ mutation. Both were successfully treated with sirolimus consistent with previous reports, but sirolimus had to be discontinued because of drug-induced hepatitis.

In adult studies, various side effects of mTOR inhibitors have been reported which include bone marrow suppression, dyslipidemia, immunosuppression, elevation of liver enzymes, renal dysfunction, pneumonitis and stomatitis. These were reversible with dose reduction $(9,10)$. In children, this drug was reported to be well tolerated in several studies with normal or high doses $\left(1-6 \mathrm{mg} / \mathrm{m}^{2} / \mathrm{d}\right)(11,12,13)$. The main side effect reported in these studies was oral mucositis. However, in a recent study, Szymanowski et al (14) investigated the efficacy and adverse effect profile of sirolimus in the treatment of severe $\mathrm{CHI}$. These authors detected adverse events such as hypertriglyceridemia, anemia, stomatitis, sepsis, varicella zoster and gut dysmotility in $80 \%$ of their patients, but also reported a $30 \%$ therapeutic success rate.

Hepatotoxicity is another known side effect of sirolimus, resulting in transient and mild increase in liver enzymes. Its incidence was reported to be $17 \%$ in patients with

Table 2. The liver enzyme levels of the patients during hepatotoxic period of sirolimus

\begin{tabular}{|c|c|c|c|c|c|c|c|c|}
\hline & \multicolumn{4}{|c|}{ Case 1} & \multicolumn{4}{|c|}{ Case 2} \\
\hline & Day 0 & Day 3 & Day 5 & Day 7 & Day 0 & Day 10 & Day 32 & Day 35 \\
\hline AST (0-40 U/L) & 298 & 68 & 144 & 51 & 261 & 32 & 46 & 76 \\
\hline ALT (0-40 U/L) & 302 & 140 & 171 & 61 & 275 & 35 & 43 & 80 \\
\hline Sirolimus dose & 3.1 & 2 & Stopped & & 0.4 & 0.2 & 0.3 & Stopped \\
\hline$\left(\mathrm{mg} / \mathrm{m}^{2} / \mathrm{d}\right)$ & Stopped & Restarted & & & Decreased & & Increased & \\
\hline
\end{tabular}

AST: aspartate aminotransferase, ALT: alanine aminotransferase 
renal transplant (15). Senniappean et al (5) and Méder et al (6) reported mild, transient elevation of liver enzyme concentrations. These increases were less than double the normal range and resolved spontaneously or with reduction in sirolimus dose $(5,6)$. Although sirolimus appears to be safe in terms of hepatotoxicity, cases with severe sirolimusinduced hepatitis have been reported. One report was that of a patient with renal transplantation who received sirolimus as an initial immunosuppressive in the post-transplant period (16). At the $16^{\text {th }}$ month post-transplant, increased liver enzyme levels were detected [maximum aspartate aminotransferase (AST): $368 \mathrm{IU} / \mathrm{L}$, alanine aminotransferase (ALT): $579 \mathrm{IU} / \mathrm{L}]$ with a serum sirolimus level of $6.3 \mathrm{ng} /$ dL. After sirolimus withdrawal, quick normalization of aminotransferases was observed. Jacques et al (17) reported another case with renal transplantation. In the second month of sirolimus, biochemical tests showed acute hepatitis (AST: $861 \mathrm{IU} / \mathrm{l}$, ALT: 609 IU/L) with signs of hepatic insufficiency. The serologic and autoimmune markers for hepatitis were normal. Despite a normal sirolimus level (10 ng/mL), it was withdrawn and transaminase levels normalized within five weeks. In our two cases, after sirolimus was discontinued in one case and decreased in the other, the normalization of transaminases was observed within a few days.

While octreotide is usually well tolerated in most patients with $\mathrm{CHI}$, octreotide induced hepatitis has been reported in a few patients $(18,19,20,21)$. Hepatitis was found to develop even with doses within the normal range, but the withdrawal of octreotide resulted in resolution. The rapid normalization of liver enzyme levels after sirolimus withdrawal and dose reduction, in our first and second case respectively, followed by elevation of transaminases after restart or dose increase and rapid normalization after sirolimus was again withdrawn while the patient continued with octreotide treatment provides robust evidence of sirolimus-induced hepatitis.

Fortunately, both patients are now normoglycemic with octreotide-LAR and frequent feedings. This observation suggests that this entity may tend to become milder over time. It also suggests that a good response to octreotide-LAR may be expected as the patients get older.

Octreotide may affect thyroid hormones and may cause hypothyroidism with a concomitant low TSH level. However, hypothyroidism with elevated TSH levels was also reported in two cases with octreotide treated $\mathrm{CHI}$ due to $A B C C 8$ gene mutation $(19,20)$. Similarly, our cases had elevated TSH levels with a low free thyroxine that is a characteristic finding for primary hypothyroidism. This is most probably a coincidental finding since patients on octreotide therapy usually develop central hypothyroidism marked by low
TSH. Further tests will be done for the etiology of primary hypothyroidism in later years.

In conclusion, sirolimus is a promising drug for diazoxide and octreotide unresponsive $\mathrm{CHI}$ patients, but physicians should be vigilant for its adverse effects which may necessitate the withdrawal of the drug.

\section{Ethics}

Informed Consent: Informed consent was taken from the patients.

Peer-review: Externally peer-reviewed.

\section{Authorship Contributions}

Surgical and Medical Practices: Belma Haliloğlu, Muhittin Çelik, Heybet Tüzün, Mehmet Nuri Özbek, Concept: Belma Haliloğlu, Design: Belma Haliloğlu, Data Collection or Processing: Belma Haliloğlu, Heybet Tüzün, Mehmet Nuri Özbek, Avni Kaya, Analysis or Interpretation: Belma Haliloğlu, Sian Ellard, Sarah E. Flanagan, Literature Search: Belma Haliloğlu, Writing: Belma Haliloğlu, Sarah E. Flanagan.

Financial Disclosure: The genetic studies were funded by the Medical Research Council (grant number: 98144). Sarah E. Flanagan has a Sir Henry Dale Fellowship jointly funded by the Wellcome Trust and the Royal Society (grant number: 105636/Z/14/Z).

\section{References}

1. Flanagan SE, Kapoor RR, Hussain K. Genetics of congenital hyperinsulinemic hypoglycemia. Semin Pediatr Surg 2011;20:13-17.

2. de Lonlay P, Fournet JC, Touati G, Groos MS, Martin D, Sevin C, Delagne V, Mayaud C, Chigot V, Sempoux C, Brusset MC, Laborde K, BellaneChantelot C, Vassault A, Rahier J, Junien C, Brunelle F, Nihoul-Fékété C, Saudubray JM, Robert JJ. Heterogeneity of persistent hyperinsulinaemic hypoglycaemia. A series of 175 cases. Eur J Pediatr 2002;161:37-48.

3. Arnoux JB, Verkarre V, Saint-Martin C, Montravers F, Brassier A, Valayannopoulos V, Brunelle F, Fournet JC, Robert JJ, Aigrain Y, Bellanné-Chantelot C, de Lonlay P. Congenital hyperinsulinism: current trends in diagnosis and therapy. Orphanet J Rare Dis 2011;6:63.

4. Güemes M, Hussain K. Hyperinsulinemic hypoglycemia. Pediatr Clin of North Am 2015;62:1017-1036. Epub 2015 May 13

5. Senniappan S, Alexandrescu S, Tatevian N, Shah P, Arya V, Flanagan S, Ellard S, Rampling D, Ashworth M, Brown RE, Hussain K. Sirolimus therapy in infants with severe hyperinsulinemic hypoglycemia. N Engl J Med 2014;370:1131-1137

6. Méder Ü, Bokodi G, Balogh L, Körner A, Szabó M, Pruhova S, Szabo AJ. Severe Hyperinsulinemic Hypoglycemia in a Neonate: Response to Sirolimus Therapy. Pediatrics 2015;136:1369-1372.

7. Abraham MB, Shetty VB, Price G, Smith N, Bock Md, Siafarikas A, Resnick S, Whan E, Ellard S, Flanagan SE, Davis EA, Jones TW, Hussain K, Choong CS. Efficacy and safety of sirolimus in a neonate with persistent hypoglycaemia following near-total pancreatectomy for hyperinsulinaemic hypoglycaemia. J Pediatr Endocrinol Metab 2015;28:1391-1398. 
8. Arya VB, Guemes M, Nessa A, Alam S, Shah P, Gilbert C, Senniappan S, Flanagan SE, Ellard S, Hussain K. Clinical and histological heterogeneity of congenital hyperinsulinism due to paternally inherited heterozygous ABCC8/KCNJ11 mutations. Eur J Endocrinol 2014;171:685-695. Epub 2014 Sep 8

9. Ventura-Aguiar P, Campistol JM, Diekmann F. Safety of mTOR inhibitors in adult solid organ transplantation. Expert Opin Drug Saf 2016;15:303-319. Epub 2016 Jan 28

10. Sankhala K, Mita A, Kelly K, Mahalingam D, Giles F, Mita M. The emerging safety profile of mTOR inhibitors, a novel class of anticancer agents. Target Oncol 2009;4:135-142. Epub 2009 Apr 21

11. Nadal M, Giraudeau B, Tavernier E, Jonville-Bera AP, Lorette G, Maruani A. Efficacy and Safety of Mammalian Target of Rapamycin Inhibitors in Vascular Anomalies: A Systematic Review. Acta Derm Venereol 2016;96:448-452.

12. Zou L, Liu Y, Pang L, Ju J, Shi Z, Zhang J, Chen X, Su X, Hu L, Shi X, Yang $X$. Efficacy and safety of rapamycin in treatment of children with epilepsy complicated with tuberous sclerosis. Zhonghua Er Ke Za Zhi 2014;52:812-816

13. Schachter AD, Benfield MR, Wyatt RJ, Grimm PC, Fennell RS, Herrin JT, Lirenman DS, McDonald RA, Munoz-Arizpe R, Harmon WE. Sirolimus pharmacokinetics in pediatric renal transplant recipients receiving calcineurin inhibitor co-therapy. Pediatr Transplant 2006; 10:914-919.

14. Szymanowski M, Estebanez MS, Padidela R, Han B, Mosinska K, Stevens A, Damaj L, Pihan-Le Bars F, Lascouts E, Reynaud R, Ferreira C, Bansept C, de Lonlay P, Saint-Martin C, Dunne MJ, Banerjee I, Arnoux JB. mTOR Inhibitors for the Treatment of Severe Congenital
Hyperinsulinism: Perspectives on Limited Therapeutic Success. J Clin Endocrinol Metab 2016;101:4719-4729. Epub 2016 Oct 3

15. Groth CG, Backman L, Morales JM, Calne R, Kreis H, Lang P, Touraine JL, Claesson K, Campistol JM, Durand D, Wramner L, Brattström C, Charpentier B. Sirolimus (rapamycine)- based therapy in human renal transplantation: similar efficacy and different toxicity compared with cyclosporine. Sirolimus European Renal Transplant Study Group. Transplantation 1999;67:1036-1042.

16. Niemczyk M, Wyzgał J, Perkowska A, Porowski D, Paczek L. Sirolimusassociated hepatotoxicity in the kidney graft recipient. Transpl Int 2005;18:1302-1303.

17. Jacques J, Dickson Z, Carrier P, Essig M, Guillaudeau A, Lacour C, Bocquentin F, Aldigier JC, Rerolle JP. Severe sirolimus-induced acute hepatitis in a renal transplant recipient. Transpl Int 2010;23:967-970. Epub 2010 May 20

18. Avatapalle B, Padidela R, Randell T, Banerjee I. Drug-induced hepatitis following use of octreotide for long-term treatment of congenital hyperinsulinism. BMJ Case Rep 2012:2012.

19. Levy-Khademi F, Irina S, Avnon-Ziv C, Levmore-Tamir M, Leder O. Octreotide-associated cholestasis and hepatitis in an infant with congenital hyperinsulinism. J Pediatr Endocrinol Metab 2015;28:449451 .

20. Koren I, Riskin A, Barthlen W, Gillis D. Hepatitis in an infant treated with octreotide for congenital hyperinsulinism. J Pediatr Endocrinol Metab 2013;26:183-185.

21. Ben-Ari J, Greenberg M, Nemet D, Edelstein E, Eliakim A. Octreotideinduced hepatitis in a child with persistent hyperinsulinemia hypoglycemia of infancy. J Pediatr Endocrinol Metab 2013;26:179-182. 